\title{
Management and Supervision of Administrative Contracts in a Federal Institution of Indirect Public Administration
}

\author{
Douglas Fernando Batista Neis ${ }^{1}$, Flávia Regina Alves de Hungria Folador ${ }^{1}$, Danielle Freire Azevedo Silva da Costa ${ }^{1}$, \\ Camila Marques de Lima ${ }^{1}$, Fábio Leite Dias ${ }^{1} \&$ Gleimiria Batista da Costa Matos ${ }^{1}$ \\ ${ }^{1}$ Public Administration, Federal University of Rondônia, Brazil \\ Correspondence: Douglas Fernando Batista Neis, Public Administration, Federal University of Rondônia, Brazil.
}

Received: November 7, 2020

Accepted: January 7, $2021 \quad$ Online Published: April 1, 2021

doi:10.5430/ijba.v12n3p1

URL: https://doi.org/10.5430/ijba.v12n3p1

\begin{abstract}
This article aims to describe the perception level of training of Brazilian Institute Foundation of Geography and Statistics (IBGE) employees who are designated in order to manage and Supervise Contracts. As described in Law No. 8,666 / 1993 and in the complementary legal framework, the performance of the contract must be monitored and supervised by a specially appointed Management representative. The bibliographic review technique was used as means of research, through the selection, record, interpretation and registration of published literature, published articles in recent journals, academic works, legislation and guidance manuals available to the public domain, as well as a data collection instrument based on a questionnaire applied to agents that exercise the role of contract inspectors into the IBGE State Units. The survey results indicate that the employees who are responsible for supervising contracts at this Foundation do not feel fully confident about having mastery of the legislation and the time needed to perform this function efficiently. In addition, they point out the complexities of legislation and some contracts as difficulties faced to carry out the tasks related to the function. The survey results indicate that the employees responsible for supervising contracts at this Foundation do not feel fully confident about having mastery of the legislation and the necessary time to perform this function efficiently. In addition, they point out the complexities of legislation and of some contracts, like difficulties faced to carry out the tasks related to the function.
\end{abstract}

Keywords: contract management, public administration, training

\section{Introduction}

Public Administration, based on the principles established in Article 37 of the Federal Constitution, has as one of its objectives to achieve the minimum waste of resources, with the promotion of the maximum efficiency and effectiveness of the public machine in favor of the optimization in the use of resources from the Brazilian society. Contractual execution is part of this process and, thus, it becomes another tool used by the Public Administration in the search for excellence in the control carried out during the fulfillment of Administrative Contracts. A lack of control in the execution of contracts certainly brings inefficiency, in contrast to the search for the implementation of better management practices, in order to achieve the fulfillment of the principles listed in Art. 37 in its entirety.

With the objective of guaranteeing the provision of better quality services, in an efficient way and, at the same time, reducing expenses, the State has concentrated on providing essential services to citizens and seeking to outsource other services that are not part of the core activity with the population (BATTAGLIO AND LEDVINKA, 2009). In this way, the public administration needs to establish different types of contracts with other parties in order to conclude their service contracts, in addition to also signing contracts when making their public purchases. Law no. 8,666 / 93 brought an exclusive chapter focused on the standardization of the Contract Supervision practices signed by the Public Administration.

It is the duty and incumbency of public agencies to supervise and monitor the provision of outsourced services, from monitoring contractual execution at the operational level to verifying compliance by the contracted company with labor, social security and tax rights resulting from the execution of the contract (MARINE et al., 2017).

Law no. 8,666 / 93 itself defines the obligation to monitor and supervise the execution of contracts signed by the Public Administration in its Art. 67 designating a person to represent it for this purpose. In this sense, Public 
Administration agents may come to accumulate this function, of contract surveyor, without prejudicing to their main function, often accumulating charges.

Art. 67. The execution of the contract must be monitored and supervised by a specially appointed Management representative, allowed to hire third parties to assist and subsidize it with information pertinent to this assignment.

$\S 1$ The Administration representative will record in his own record all occurrences related to the execution of the contract, determining what is necessary to regularize the observed absences or defects.

$\S 2$ The decisions and measures that go beyond the competence of the representative must be requested to his superiors in a timely manner for the adoption of the appropriate measures ( $\operatorname{Law~n}^{\circ} 8.666$ / 93).

In order to fulfill the contract surveyor's assignment with the required effectiveness demanded by the Public Administration, it must take into account the specific knowledge required by the agents who are responsible for monitoring and supervising contracts under Law No. 8.666 / 1993 (OLIVEIRA JUNIOR, 2016). In view of this scenario, the role of the management agent, to whom this function is assigned, has a fundamental importance for the objectives to be achieved efficiently and effectively.

The relevance of this research consists of the facts that the State seeks better management practices in order to achieve full transparency in the use of public resources and, in the social aspect, seeks to optimize the control of actions related to contracting and the effective fulfillment of contracts arising from these contracts, in order to demonstrate the effective allocation of public resources, so that society has the proper perception of the professionalism and commitment of the Public Administration to achieve such objectives, based on the employment of specialized, committed and competent agents to perform the tasks of contract management and supervision functions, as provided by Law No. 8.666 / 93.

In Brazil, Public Administration is divided into direct and indirect, according to Decree-Law 200/1967 and, while the first is centralized under the Presidency of the Republic and Ministries, indirect administration comprises entities with their own legal personality, such as Foundations, Municipalities, Public Companies, among others (MELLO, 2010). Among the institutions that make up the indirect Public Administration is IBGE (Brazilian Institute Foundation of Geography and Statistics), a foundation that is subject to the same Laws as the other civil agencies regarding to Public Management.

Brazilian Institute Foundation of Geography and Statistics (IBGE) is an entity of the federal public administration, linked to the Ministry of Economy and constitutes the main provider of data and information of the country, which meet the needs of the most diverse segments of civil society, as well as the federal, state and municipal government agencies. It consists of 27 State Units that are subordinate to four boards and two general coordinations: Executive Board (DE), Geoscience Board (DGC), Research Board (DPE), Informatics Board (DI), Documentation and Dissemination Center of Information (CDDI) and National School of Statistical Sciences (ENCE).

The Executive Board is divided into 4 Coordinations: Human Resources, Budget and Finances, Planning and Supervision, and Material Resources, where this last one is responsible for asset management, supply and shipping, engineering and fleet, as well as the purchase of goods and services. The contracts arising from these purchases are signed in the light of Law 8666/1993 and, at IBGE, by virtue of an internal regulatory instrument, the execution of the contract is supervised and monitored by employees specially designated for this task, called Contract Execution Manager and Contract Administrative Manager, who are appointed by the person responsible for the area that demanded the contract, to which the contract is linked, and appointed by the Executive Director (Resolution of Director Board - R. CD. No. 15/2005), by means of a Designation Ordinance and supervised by civil servants under the regulations of CRM Service Order (Coordination of Material Resources) no. 03/2017.

In order to guide this research, the following problem was established: What is the perception of training that IBGE civil servants have for the performance of their functions as Contract Surveyors, according to the provisions of Law No. 8.666 / 1993 ?

The general objective of this work is to analyze the level of qualification perception of IBGE civil servants designated for the Management and Supervision of Contracts, according to the provisions of Law No. 8.666 / 1993 and the complementary legal framework.

As specific objectives, this work aimed to identify possible difficulties faced by Contract Surveyors during the execution of tasks, given the current legal provisions, as well as to survey the main deficiencies related to training perceived by the participants with their experiences during the performance of the function, in order to comply with all legal requirements and with the efficiency provided for in Law No. 8.666 / 93. 
In addition to this introduction, the article is structured as follows: theoretical framework, where the concepts of the current literature on management and inspection of administrative contracts were dealt with, as well as the main concepts involving public procurement in Brazil; then the methodology, containing the procedures adopted for the development of the research, the approach taken and the statistical parameters used; finally, the analysis and discussion of the results, concluding the present work through the topic of the conclusions and the contribution with the existing literature.

\section{Literature Review}

In this topic, the main concepts and recent studies carried out in the area of Management and Supervision of Administrative Contracts will be discussed, based on an analysis of Administrative Contracts, Public Contracts, the specificities and exorbitant clauses that differentiate administrative contracts from Law Private contracts and, lastly, of Contract Management and Supervision and its application at Brazilian Institute Foundation of Geography and Statistics, an institution belonging to the Indirect Federal Public Administration.

\subsection{Administrative Contracts in Indirect Administration}

Contract can be understood as a legal relationship established by an agreement of wills between the parties, in which they are obliged to each other with the provision of opposing obligations, that is, a form of peaceful composition of interests. For Public Administration, not all legal relationships established with third parties result from unilateral acts and, therefore, many of these relationships come from agreements of will between the Government and third parties (MELLO, 2010).

Administrative contracts work as an adjustment established between the parties, namely, Public Administration, acting in this capacity, and third parties, or only between administrative entities, submitted to the legal-administrative regime for the achievement of public interest objectives (MAZZA, 2015).

Although contracts are characteristically within the sphere of Private Law, this institute is also used by the Public Administration, either in its original form, through private contracts, or with necessary adaptations concerning public affairs, understood as administrative contracts (OLIVEIRA JUNIOR et al., 2016).

It is emphasized that the Public Administration, also with regard to the Management and Supervision of Contracts, the focus of this research, is governed by principles that must be permanently pursued in order to guide the work of the agents in charge of these tasks, as governed by the Federal Constitution 1988:

Art. 37 - The direct and indirect public administration of any of the Powers of the Union, the States, the Federal District and the Municipalities will obey the principles of legality, impersonality, morality, publicity and efficiency (BRASIL, 1988).

Thus, there are some peculiarities that govern administrative contracts, by virtue of rules and principles of Public Law that aim at the supremacy of the public interest over the private, using the precepts of Private Law only in a complementary way. It can be said, therefore, that the rules of Public Law overlap those of Private Law, not replacing or derogating from the private rules of Public Administration (OLIVEIRA JUNIORet al., 2016).

When it comes to Private Law, there is the broad and informal freedom in relation to contracting, with the exception of the provisions supported by Law. In contrast, when it comes to the Public Administration, it is subject to certain content limitations and the rigor of formal requirements, with the difference of being able to use the exorbitant clauses, a kind of administrative privileges, with regard to the fixation and alteration of clauses, including unilaterally in some cases, which the legislator understood as necessary to protect public interests (MELLO, 2010).

Tadelis (2012) emphasizes the importance of public procurement regulation as a mechanism that guarantees equal opportunities in competition, as well as protecting the public interest and promoting transparency. Also according to the author, such principles justify the existence of these mechanisms, such as those instituted by Law No. 8,666, of June 21, 1993, Brazilian Bidding Law, as in the case of the Federal Acquisition Regulations - FARs, American legislation, and in other countries, where the Public Administration uses regulations that purposely limit the forms of negotiation with the same objective.

\subsection{Public Outsourcing and Its Effectiveness}

The outsourcing carried out by the Public Administration must occur through bidding processes, as prescribed in article 37 of the Constitution of the Federative Republic of Brazil and Law No. 8,666/93. The Bidding Law expresses that the Public Administration, in its contracting with third parties, in the execution of works and services, including advertising, disposals, permissions, leases and public purchases, a prior bidding must be made, with exceptions provided for in same legal regulation. 
For these exceptions, Law 8,666 / 93 allows some contracts to be carried out with no requirement or no bidding, according to the established criteria, according to the needs of the Management.

The State outsources in order to provide the various ways it needs as support to carry out its main activities, its core activities, and when secure at outsources to meet these demands, whether for different goods or services, it must be choosen the most advantageous proposal, allowing, however, wide competition, so that all suppliers that come to meet the qualification requirements are able to participate in the event.

According to Law No. 8.666 / 93:

Art. 2 - The works, services, including advertising, purchases, disposals, concessions, permissions and leases of the Public Administration, when contracted with third parties, will necessarily be preceded by a bidding process, except in the cases provided for in this Law.

Art. 3 - The bidding process is intended to guarantee the observance of the constitutional principle of isonomy, the selection of the most advantageous proposal for the administration and the promotion of sustainable national development and will be processed and judged in strict accordance with the basic principles of legality, impersonality, morality, equality, publicity, administrative probity, attachment to the summoning instrument, objective judgment and those related to them (BRASIL, 1993).

As it can be seen, Article 3 of Law 8,666 / 93 expresses the fundamental principles of public biddings, namely: legality; isonomy; impersonality; morality and administrative probity; publicity; link to the invitation to bid; objective judgment; speed; this last principle, enshrined by Law No. 10,520 of 2002 as one of the precepts that govern the biddings held in the trading session, aims to simplify procedures of excessive rigidity and inefficient formalities.

\subsection{The Peculiarities and Exorbitant Clauses in Administrative Contracts}

After the bidding process, it is necessary to sign an administrative contract between the direct, indirect or foundational Public Administration and the supplier of the goods or services. However, according to Law 8,666 / 93, there are some exceptions, and the pact can be replaced by other skillful instruments, such as, letter of contract, note of commitment to expenditure, purchase authorization or order to perform services.

With regard to Administrative Contracts, the pre-established conditions "subject to changeable public interest impositions", identifying an important institute present in these contracts, as it refers to the supremacy of the public interest over the private, so that in a contract with the Public Administration there is the presence of so-called exorbitant clauses, which are prerogatives that favor the Administration, based, precisely, on the public interest they protect (MELLO, 2010).

Due to the term of validity of the contracts for the provision of continued services of indirect execution with exclusive dedication of labor, these are the most likely to use the exorbitant clauses, alien to the Private Law institutes, as already expressed. However, they also integrate the types of Administrative Contracts because they are endowed with public interest. They are not clauses that aim to give the Public Administration exceptional powers, but rather to protect the supremacy of the public interest over the private interest (ZUCOLOTO, 2019).

Under Law No. 8,666 / 93, the exorbitant clauses:

Art. 58 - The legal regime of administrative contracts established by this Law gives the Administration, in relation to them, the prerogative of:

I - modify them, unilaterally, to better suit the purposes of public interest, respecting the contractor's rights;

II - terminate them, unilaterally, in the cases specified in item I of art. 79 of this Law;

III - supervise their execution;

IV - apply sanctions motivated by the total or partial non-execution of the adjustment;

$\mathrm{V}$ - in the case of essential services, provisionally occupy movable, immovable, personal and services related to the object of the contract, in the event of the need to safeguard administrative determination of contractual absences by the contractor, as well as in the event of termination of the administrative contract.

$\S 1^{\circ}$ The economic, financial and monetary clauses of the administrative contracts cannot be changed without the prior agreement of the contractor.

$\S 2^{\circ}$ In the event of item I of this article, the economic and financial clauses of the contract must be revised in order to maintain the contractual balance. 
Art. 59 - The declaration of nullity of the administrative contract operates retroactively preventing the legal effects that it, ordinarily, should produce, in addition to dismantling those already produced.

Single paragraph. The nullity does not release the Administration from the duty to indemnify the contractor for what he has performed until the date on which it is declared and for other losses regularly proven, as long as it is not imputable to him, promoting the responsibility of those who caused him (BRASIL, 1993).

In the presented scenario, therefore, Public Administration agents, designated as contract surveyors, must have full capacity and knowledge of the entire regulatory framework that guides the application of the planned institutes, with a view to enforcing the aforementioned Public Administration principles previously and, for that, they must be properly trained to fulfill this function. These agents are the tools of the Administration to ensure that the objectives of Public Management are fully achieved and the principles are respected, so that the resources of Brazilian society are applied in an efficient, effective and a successful manner. The importance of public agents in acting as Contracts Surveyors has already been addressed previously and at this point the specific emphasis of Art. 67

\subsection{Management and Supervision of Contracts at IBGE and Their Application}

The "supervision of contracts" is an activity carried out by the public administration that aims to control, monitor and inspect the faithful fulfillment of the obligations assumed by the contracting parties. Therefore, it must be guided by principles of efficiency, effectiveness and successfulness, in addition to the other principles that govern public administration, in order to ensure that the execution of the contract occurs with quality and in compliance with the current legislation.

In order to standardize the management and supervision of IBGE contracts, in 2010 a contract supervision manual was created, which aims to help the contract surveyors at IBGE to carry out their activities seriously and consistently, in a minimally parameterized and transparently.

The manual was created based on R. CD. no. 15/2005, which establishes a system for the supervision, monitoring and management of contracts for continuing services and those for supplying future obligations, which establishes the obligations of administrative surveyors and the execution of contracts, as well as establishing that surveyors must have total knowledge of the contract by which it will be tax.

Art. 2 - All contracts under the responsibility of the IBGE Units must be accompanied by administrative surveyors and supervised by execution surveyors, designated through the Executive Director's Ordinance and published in a Service Bulletin. (R. CD. No 15/2005)

For the purpose of recording the monitoring, supervision and evaluation of contracts, IBGE instituted the Contract Supervision System, available on the organ's intranet page, through the CRM Service Order No. 03/2017, where the surveyors must make the records in 03 (three) stages, to know:

Art. 2 - The records in the Supervision System are subdivided into 03 (three) stages:

1st stage - Entry: process, contract and manager data, which will be automatically filled in with the information registered in the Contract System - SDA, and in the case of labor contracts, information from third parties;

2nd stage - Occurrence: report of contractual occurrences accompanied by the Administrative and Executive Managers, for the adoption of timely measures in cases of default;

3rd stage - Evaluation: monitoring by the Administrative Manager regarding the initial and periodic evaluations, social security, labor and regularity obligations and, also, by the Executive Manager regarding the provision of services;

Thus, from these presented standards, we can have the exact notion of what the execution of this task represents for a designated server and all the responsibility that falls on him.

\section{Methodology}

Regarding the used methods in order to achieve the proposed objectives, a deductive approach, of a mixed method nature, was used in order to understand and describe the meaning that participants attribute to a given problem from the application of the data collection (CRESWELL, 2010). The bibliographic review technique was used as a means of research, through the selection, record, interpretation and registration of published works, published articles in recent journals, academic works, legislation and guidance manuals available to the public domain, as well as a data collection instrument based on a questionnaire applied to agents who exercise the role of contract surveyors in the IBGE State Units. 
All contract surveyors, both administrative and execution, are appointed through Ordinances, that is, everyone has full knowledge of their function. The questionnaires were applied with these servers in order to verify the applicability of the CRM Service Order No. 03/2017, in 2018, and the perception of the servers regarding the performance of the contract surveyor.

The data collection instrument was adapted, using as a base Zucoloto (2019) and Neis e Silva's (2020) questionnaires, being performed an adaptation of the original questionnaire, relevant the objectives of this work, modifying the format in questions for assertions. It also included new assertions aligned with the established objectives and, for its application, the 5-point Likert scale was used, with a total of 16 statements.

The Likert scale, as used in this research, aims to obtain the measures of attitudes of the agents designated to perform the tasks of Contract Surveyor, in view of the complexity of the activities that comprise this function, as exposed.

The Likert scale is a balanced comparison scale, with an odd number of categories and a neutral position. Named after its creator, Rensis Likert, the Likert scale requires respondents to indicate a degree of agreement or disagreement with each of a series of statements about stimulus objects. Generally, each item on the scale has five response categories, ranging from "totally disagree" to "totally agree" (MALHOTRA, 2012); so it was like that the scale was used in this research.

Adaptations were made from sections III and IV of the data collection instrument by Zucoloto (2019), and inclusion of assertions in the light of the theory studied, it was obtained the data collection instrument to be submitted to research participants, agents responsible for supervision contracts at IBGE, as shown in Table 1.

Table 1. Data collection instrument

\begin{tabular}{ll}
\hline Assertive & Zucoloto's original questionnaire (2019) \\
\hline Q2 & $\begin{array}{l}\text { In your opinion, how do you evaluate the time you had or have in } \\
\text { the supervision of outsourced service contracts to carry out the } \\
\text { supervision in an efficient manner? }\end{array}$
\end{tabular}

Previously or during the inspection, did you receive training and
Q1
service contracts?

\begin{tabular}{|c|c|c|}
\hline Q5 & $\begin{array}{l}\text { In your opinion, was your knowledge or is it sufficient to carry out } \\
\text { the duties of supervising outsourced service contracts? }\end{array}$ & $\begin{array}{l}\text { I have full control over the } \\
\text { duties of Contract Surveyor. }\end{array}$ \\
\hline Q13 & $\begin{array}{l}\text { In your opinion, was your mastery of the legislation pertaining to } \\
\text { outsourced service contracts, in an inclusive manner, Law No. } \\
8.666 \text { of } 1993 \text { and Normative Instruction No. } 05 \text { of } 2017 \text { or is it } \\
\text { sufficient to carry out the supervision of outsourced service } \\
\text { contracts? }\end{array}$ & $\begin{array}{l}\text { I have mastered the } \\
\text { legislation pertaining to } \\
\text { administrative contracts, } \\
\text { particularly Law No. 8,666 } \\
\text { of } 1993 \text {. }\end{array}$ \\
\hline \multirow[t]{2}{*}{ Q14 } & $\begin{array}{l}\text { In your opinion, was your mastery of the legislation pertaining to } \\
\text { outsourced service contracts, in an inclusive manner, Law No. } \\
8.666 \text { of } 1993 \text { and Normative Instruction No. } 05 \text { of } 2017 \text { or is it } \\
\text { sufficient to carry out the supervision of outsourced service } \\
\text { contracts? }\end{array}$ & $\begin{array}{l}\text { I have mastered the rules } \\
\text { contained in R. CD no. } \\
15 / 2005 \text { and CRM Service } \\
\text { Order no. 03/2017. }\end{array}$ \\
\hline & \multicolumn{2}{|l|}{ Other questions (assertive) } \\
\hline Q3 & \multicolumn{2}{|c|}{$\begin{array}{l}\text { In my State Unit, there are enough servers to supervise the contracts in force so as not to overload } \\
\text { any server. }\end{array}$} \\
\hline $\mathrm{Q} 4$ & \multicolumn{2}{|c|}{ I have always accumulated the function of Contract Surveyor with another function in my Unit. } \\
\hline Q6 & \multicolumn{2}{|c|}{$\begin{array}{l}\text { In my State Unit, the choice by the surveyor of each contract is made based on the technical } \\
\text { knowledge of the server who will be appointed to do so }\end{array}$} \\
\hline Q7 & \multicolumn{2}{|c|}{ My knowledge is sufficient to carry out contract supervision duties efficiently. } \\
\hline
\end{tabular}

Questionnaire adapted for this research

The time I have for the supervision of contracts is sufficient to carry out the task efficiently.

I believe I have received enough training and improvement to perform the function of contract surveyor.

I have full control over the durtes of Contract Surveyor. legislation pertaining to administrative contracts, particularly Law No. 8,666 I have mastered the rules contained in R. CD no. 15/2005 and CRM Service . 


\begin{tabular}{|c|c|}
\hline Q8 & $\begin{array}{l}\text { The monthly procedures pertinent to the supervision of contracts are, in fact, performed by the } \\
\text { ordained server. }\end{array}$ \\
\hline Q9 & $\begin{array}{l}\text { The legislation dealing with the performance of the Contracts Surveyor function is broad and } \\
\text { complex. }\end{array}$ \\
\hline Q10 & There are types of contracts that are more complex to supervise than others. \\
\hline Q11 & $\begin{array}{l}\text { "Exorbitant clauses are prerogatives that favor the Administration, based, precisely, on the public } \\
\text { interest that they protect" (ZUCOLOTO, 2019). I am fully aware of the Exorbitant Clauses of } \\
\text { Administrative Contracts. }\end{array}$ \\
\hline Q12 & $\begin{array}{l}\text { During the execution of the supervision of contracts, I had difficulties to perform some tasks } \\
\text { related to the function. }\end{array}$ \\
\hline Q15 & $\begin{array}{l}\text { During the execution of the supervision of contracts, I felt full confidence to carry out the tasks } \\
\text { related to the function. }\end{array}$ \\
\hline Q16 & $\begin{array}{l}\text { As contract surveyor, when I identified partial non-performance of the contract, I always took the } \\
\text { appropriate measures, according to the legislation, as well as inserting the relevant information in } \\
\text { the IBGE's contract superviosion system. }\end{array}$ \\
\hline
\end{tabular}

Source: Elaborated by the authors, adapted from Zucoloto (2019) and Neis e Silva (2020).

In addition to the statements adapted from the aforementioned work, other issues related to the theme and the execution of Contract Supervision by the responsible agents, according to the theory studied, were included for the elaboration of the final data collection instrument used in this research. As options for responses, all statements used the 5-point Likert scale. The results obtained were tabulated using the Software SPSS v. 24. and for the analyzes, the parameters of descriptive statistics were applied, using the mean and Ranking Mrhodium (RM).

Using the RM, according to the responses of the data collection instrument submitted to the participants, and the respective frequencies of responses, the weighted average for each statement was calculated from the statistical parameters:

Formula used to calculate the Average Ranking:

$$
R M=
$$

Where:

RM Average Ranking;

$f_{i}$ Observed frequency of each response for each attribute;

$v_{i}$ Scale value (from 1 to 5 );

$n$ Sample value;

After its elaboration, the data collection instrument was subjected to a previous reliability test, being sent to 5 respondents, and it was found that the questions showed the ability to obtain the results according to the objectives proposed by this study. For Malhotra (2012), the alpha coefficient, or Cronbach's alpha, is the average of all fifty-fifty coefficients that result from the different ways of dividing the scale items. This coefficient varies from 0 to 1 , and a value equal to or less than 0.6 can indicate unsatisfactory internal consistency reliability. Therefore, the greater the result obtained for the alpha coefficient, the greater the reliability of the data collection instrument in obtaining the intended data. SPSS v software was used. 24 to calculate the alpha coefficient, obtaining the value of 0.7867 , as shown in Table 2 below:

Table 2. Reliability statistics for the pre-test

\begin{tabular}{ll}
\hline Statistics of reliability & \\
\hline CronbachAlpha's & Number of assertives \\
\hline 07867 & 16 \\
\hline
\end{tabular}

Source: Prepared by the authors. 
After performing the previous test and verifying the validity and reliability of the data collection instrument, it was submitted to a total of 30 respondents, all agents responsible for the function of supervising contracts at IBGE.

\section{Data Analysis and Discussion}

The next step is the presentation of the analysis of the results obtained with the application of the data collection instrument, of the demonstration of the validity and reliability of the constructs, based on the statistical calculations used, performing the representation of the tabulation of the collected data and, later, the discussion of the results is presented, in the light of the theoretical framework of this research.

\subsection{Analysis of Results}

After sending the data collection instrument to the 30 agents participating in the research and obtaining the respective answers, the alpha coefficient was calculated again, Cronbach's Alpha, in the same way exposed for the previous reliability test, but this time with the total number of respondents, obtaining a value of 0.7417 .

Thus, it was found that the data collection instrument proved to be valid and reliable. In addition, the coefficient for each statement was calculated, so that it was possible to observe the reliability of each construct.

The Table 3 contains the results obtained with the calculation of the coefficient value after obtaining the answers for each statement of the data collection instrument. In the same way used in the previous test and for the complete data collection instrument, the SPSS v. 24 software was used to perform the calculations for each statement.

With the Cronbach's Alpha value obtained for each statement, it was found that all of them obtained values greater than 0.6 , corroborating the feasibility and reliability of the data collection instrument used.

Table 3. Reliability statistics for each statement

\begin{tabular}{ll}
\hline Variable & Alpha Value \\
\hline Q1 & 0.9953 \\
\hline Q2 & 0.9952 \\
\hline Q3 & 0.9952 \\
\hline Q4 & 0.9955 \\
\hline Q5 & 0.9950 \\
\hline Q6 & 0.9957 \\
\hline Q7 & 0.9951 \\
\hline Q8 & 0.9949 \\
\hline Q9 & 0.9951 \\
\hline Q10 & 0.9958 \\
\hline Q11 & 0.9949 \\
\hline Q12 & 0.9951 \\
\hline Q13 & 0.9949 \\
\hline Q14 & 0.9952 \\
\hline Q15 & 0.9956 \\
\hline Q16 & 0.9949
\end{tabular}

Source: Prepared by the authors.

In order to analyze each statement, the Average Ranking for each one was calculated, based on the answers obtained, reaching the results as shown in Table 4. Each column represents an assertion, from Q1 to Q16, and the lines represent the Average Ranking obtained for each question. 
Table 4. Average ranking of each statement

\begin{tabular}{ll}
\hline Average Ranking & \\
\hline Q1 & 2.53 \\
\hline Q2 & 2.63 \\
\hline Q3 & 2.67 \\
\hline Q4 & 4.63 \\
\hline Q5 & 2.97 \\
\hline Q6 & 2.13 \\
\hline Q7 & 2.77 \\
\hline Q8 & 3.53 \\
\hline Q9 & 4.27 \\
\hline Q10 & 4.87 \\
\hline Q11 & 3.20 \\
\hline Q12 & 4.17 \\
\hline Q13 & 3.77 \\
\hline Q14 & 2.67 \\
\hline Q15 & 2.23 \\
\hline Q16 & 3.53 \\
\hline
\end{tabular}

Source: Prepared by the authors.

Based on the values obtained for the demonstrated reliability statistics and for the average ranking of each statement, the results are discussed in order to achieve the general and specific objectives proposed by this research.

Through the analysis of the results obtained for the average ranking of the assertions with a focus on the defined objectives, we will describe difficulties encountered and deficiencies related to training in the perception of the organization's employees.

It was verified with the obtained result for the assertion Q1, that the IBGE agents responsible for the supervision of the contracts, for the most part, believe that they have not received sufficient training and improvement, which corroborates with the results of Q5 and Q7, which indicate that respondents do not believe they have mastery over the duties of a contract surveyor and neither do they have sufficient knowledge to perform tasks efficiently. It is also verified that the respondents, despite believing they have the necessary knowledge about Law No. 8,666 / 93, do not have mastery of the internal normative instruments related to the supervision of contracts.

All of these results are consistent with the result obtained for statement Q15, which demonstrates the agents' lack of confidence in carrying out the tasks relevant to the function, thus pointing to the need for periodic professional development programs to be developed by the agency itself, include the entire staff of tax agents, aiming at better preparation for the performance of their duties.

It is also possible to observe, from the high level of agreement in statement Q4, that respondents in general accumulate the function of surveyor with other functions in their units. Corroborating this result, it can be seen in Q2 and Q3, that the respondents believe they do not have time to exercise the function of contract surveyor efficiently, as well as that there are not enough servers in the IBGE State Units to perform the function.

The accumulation of functions added to the insufficiency of servers to inspect the institution's contracts in order not to overload any server certainly make it difficult for them to perform the tasks with the desired efficiency. These results are consistent with those found by Zucoloto (2019) and Neis e Silva (2020), who analyzed the perception of contract surveyors in a Higher Education Institution and in a Military Institution, respectively.

The result of the average ranking of assertion Q12 shows that respondents find it difficult to perform tasks related to function. This result corroborates with the result of the statement Q10, which indicates a high level of agreement by the respondents on the perception that some contracts are more complex to be inspected than others, as well as with the result obtained for Q9, which shows that the surveyors consider the legislation which deals with broad and complex contract enforcement. This may be due to the lack of specialization or deepening in certain types of contracts, since the surveyors of these are not chosen according to the technical knowledge about the object of the contract to be supervised, 
as can be verified with the result obtained in the statement Q6. As noted in the research by Neis and Silva (2020), the distributions of the contracts by affinity with the surveyor functions would be more appropriate.

As for the partial non-execution of contracts, the results of assertion Q16 indicate that the civil servants reported adopting the appropriate measures in accordance with the legislation, as well as inserting the information in the IBGE's contract supervision system. In this statement, the respondents indicated that they have a good ethical perception in relation to their functional duty and their assignment as public procurement surveyor.

\section{Conclusions}

Efficiency is one of the principles established by the Federal Constitution and optimizing the use of resources from Brazilian society is a way to achieve this efficiency.

The Public Administration, due to the contracting of outsourced and essential services and also the purchase of goods, has several types of contracts with other parties. And these need to be monitored and supervised in order to avoid wastes or non-compliance with the agreed obligations.

This research sought to show the concepts and recent studies carried out in the area of Management and Supervision of Administrative Contracts and their application at Brazilian Institute Foundation of Geography and Statistics - IBGE.

The research showed that a contract is a legal relationship by an agreement of wills between the parties and, for the Public Administration, many of these relationships come from agreements of will between the Public Power and third parties. In Public Administration, contracts are signed as a result of bidding processes, which are carried out in order to choose the most advantageous proposal through a wide competition between suppliers.

However, administrative contracts have prerogatives that favor the Administration, based on the public interest, such as the possibility of unilateral amendment of the contract by the Administration, its unilateral termination, the supervision of the contract, the possibility of applying penalties for non-performance. These are called exorbitant clauses.

Law 8,666 / 1993, in its art. 67, says that the execution of the contract must be monitored and supervised by a specially appointed Management representative. For this, it is of fundamental importance that this representative has full knowledge of his role as supervisor, as well as the relevant legislation.

The supervision of IBGE contracts is governed by a manual that was instituted in 2010 with the objective of contributing so that contract surveyors could exercise their activities seriously and consistently, in a minimally parameterized and transparent manner. And, for the purposes of registering the monitoring, supervision and evaluation of contracts, IBGE instituted the Contract Supervision System, available on the organ's intranet page, through the CRM Service Order No. 03/2017.

As a corollary of the research, it was possible to verify that the civil servants responsible for the supervision of contracts in this Foundation consider that they have a certain mastery of the current legislation, but still do not feel fully confident about having the necessary knowledge about the duties of the function, not even the necessary time to perform this function efficiently. The complexity of the legislation and some contracts were also indicated as difficulties faced by surveyors, pointing to the need for better training of these professionals.

Therefore, the general objective of the research was achieved, where it was possible to obtain information regarding the level of perception of the training of the employees designated for the Supervision of contracts in this public institution of the indirect administration. Through the data collection instrument, responses were obtained that demonstrated the existence of difficulties in mastering, training and in carrying out the duties of contract inspection.

Other difficulties considered by agents during the supervision of contracts are the time, the accumulation of functions, the complexity of the matter, the lack of servers for this task, culminating in the choice of the server due to availability and not due to his knowledge, resulting in a decrease in confidence in the full accomplishment of tasks. Regarding the training to perform the tasks, it is noticed that the unavailability and lack of time to train are contributing factors for the low notion of full knowledge of the legislation used in the exercise of inspection activities.

As the main contribution to the currently existing literature, the confirmation of the importance of the perception of training that contract surveyors must have, as they are aware of their attributions according to the law, can perform the function with a higher level of confidence and, in this way, stands out increasing the levels of efficiency and effectiveness in the management of Public Contracts. In addition, further research involving more comprehensive fields of public service may be carried out in the future, with a view to improving analyzes of the influence of the perception of training and of the training itself in the optimization of public procurement management indexes.

The research in question, seeking to obtain a vision of a partial and specific reality, was limited to a certain sample and in only one Institution belonging to the Public Administration of Brazil. In view of this, it is deemed necessary that 
more in-depth research (with interviews or open questions) be carried out with the same sample, or that $n$ sample be expanded, enabling a comparative study on the topic.

\section{References}

Battaglio, R. P. Jr., \& Ledvinka, C. B. (2009). Privatizing human resources in the public sector. Review of Public Personnel Administration, 29(3), 293-307.

Creswell, J. (2010). Projeto de pesquisa: métodos qualitativo, quantitativo e misto (3rd ed.). Porto Alegre: Booking: Artmed.

IBGE. (2008). Directing Council Resolution No. 15/2005. Institutes a new system of supervision, monitoring and management of Contracts at IBGE. Retrieved August 29, 2008, from http://w3.siad.sda.ibge.gov.br/SIAD/atoAdministrativoConsulta.jsf?codOrgao $=800001 \& \operatorname{codTipoAto}=8 \&$ ano $=2$ $005 \&$ numAto $=15$

IBGE. (2010). CRM Service Order 07/2010. Establishes the Contracts Monitoring and Supervision Manual. Retrieved November 3, 2010, from http://w3.de.ibge.gov.br/DECRM/Legislacao_Normas_Pareceres/Ordens_de_Servicos/25.0-Ordem\%20de\%20S ervi\%C3\%A7o\%20CRM\%20n\%C2\%BA\%207\%20-\%20Institui\%20\%20Manual\%20of\%20Follow-up\%20e\%2 0Check\%C3\%A7\%C3\%A3o\%20\%20Contratos.pdf

IBGE. (2017). CRM Service Order 03/2017. Establishes the Contract Supervision System. Retrieved December 21, 2017 ,

from http://w3.de.ibge.gov.br/DECRM/Legislacao_Normas_Pareceres/Ordens_de_Servicos/43\%20-\%20Ordem\%20d e\%20Servi\%C3\%A7o\%20CRM\%20N\%C2\%BA\%20003-2017\%20-\%20Check\%C3\%A7\%C3\%A3o\%20of\%2 0Contratos.pdf

Law. (1988). Federal Constitution. Official Gazette of the Federative Republic of Brazil, Brasília, DF. Retrieved from http://www.planalto.gov.br/ccivil_03/constituicao/constituicao.htm

Law. (1993). Regulates art. 37, item XXI, of the Federal Constitution, establishes rules for public tenders and contracts and gives other measures. Official Gazette of the Federative Republic of Brazil, Brasília, DF. Retrieved from http://www.planalto.gov.br/ccivil_03/leis/18666cons.htm

Malhotra, N. K. (2012). Pesquisa de Marketing: Uma orientação aplicada (6th ed.). [S.1.] 2012.

Marinho, R. De. C. P., et al.. (2018). Fiscalização de contratos de serviços terceirizados: desafios para a universidade pública. Gest. Prod., São Carlos, 25(3), 444-445. Retrieved September 25, 2019, from http://www.scielo.br/scielo.php?script=sci_arttext\&pid=S0104-530X2018000300444\&lng=en\&nrm=iso

Mazza, A. (2015). Manual de direito administrativo (5th ed.). São Paulo: Saraiva.

Mello, C. A. B. De. (2010). Curso de direito administrativo (27th ed.). São Paulo: Malheiros.

Neis, D. F. B., \& Silva, R. M. P. Da. (2020). Percepção de capacitação de agentes militares da administração pública para a fiscalização de contratos administrativos. Acanto em Revista. Rio de Janeiro, Brazil. Ano VII - $\mathrm{n}^{\circ} 7$ - 2020. Retrieved September 29, 2020, from https://pt.calameo.com/read/0057038179bc34af3cde3

Oliveira Junior, N. J., \& Santos, E. A. Os. (2016). A necessidade de conhecimentos específicos para o fiel cumprimento do acompanhamento e fiscalização de contratos no âmbito da AP segundo o disposto no Art. 67 da Lei 8.666/1993. Revista de Administração de Roraima - RARR, 6(2), 500-519. Retrieved from https://revista.ufrr.br/adminrr/article/view/3517

Tadelis, S. (2012). Public procurement design: lessons from the private sector. International Journal of Industrial Organization, 30(3), 297-302.

Zucoloto, I. E. (2019). Gestão e fiscalização de contratos de serviços terceirizados em uma instituição federal de ensino. Universidade Federal do Espírito Santo.

\section{Copyrights}

Copyright for this article is retained by the author(s), with first publication rights granted to the journal.

This is an open-access article distributed under the terms and conditions of the Creative Commons Attribution license (http://creativecommons.org/licenses/by/4.0/). 